\title{
WALTER BENJAMIN, TAITEEN TOINEN TEKNIIKKA JA AVANTGARDEN KULTTUURIPOLITIIKKA
}

\section{Walter Benjamin, second tecnique of art and cultural policy of avantgarde}

\begin{abstract}
This article provides a fresh look into Walter Benjamin's famous essay, "Artwork in the Age of Mechanical Reproduction" (1936). Following Benjamin scholar Esther Leslie, we claim that Benjamin's lesser-known concept of "second technique" is integral for understanding both the meaning of essay as well as mapping the political and artistic aims of the 1920's avant-garde movements in general. The article is structured around two cases of avant-garde, both of which are central already for Benjamin, but remain somewhat under-theorized in connection to Benjamin. These are the Soviet constructivist film and the idea of glass construction in Weimar-era German architecture.
\end{abstract}

Keywords: Walter Benjamin, second technique of art, avantgarde, film, architecture

\section{Johdanto}

Walter Benjaminin (1892-1940) Taideteos teknisen uusinnettavuuden aikakaudella (Das Kunstwerk im Zeitalter seiner technischen Reproduzierbarkeit, jatkossa Taideteos-essee) on teksti, johon palataan toistuvasti tieteen- ja taiteenrajat ylittäen (ks. esim. Gumbrecht \& Marinnan, 2003). Taideteos-esseen keskeisin ajatus on, että kysymys taideteoksen luonteesta on aina vallitsevien teknisten tuotantotapojen kautta määrittyvä. Benjamin ei kuitenkaan käsittele tätä taiteen ja tekniikan välistä suhdetta ainoastaan ymmärtääkseen taiteentuotannon luonnetta itsessään, vaan hänen mukaansa tähän suhteeseen ja siinä tapahtuviin muutoksiin liittyy aina myös mahdollisuus muuttaa vallitsevia yhteiskunnallisia olosuhteita. Hieman yllättäenkin tämä ulottuvuus on jäänyt monessa Taideteos-esseetä käsittelevässä tutkimuksessa kuitenkin vähemmälle huomiolle, ainakin verrattuna tekstin tunnetuimpaan teesiin taideteoksen aurasta ja sen muuttumisesta.
Tämän artikkelin tavoitteena on käsitellä Benjaminin tutkimaa taiteen ja tekniikan välistä suhdetta ensisijaisesti juuri siihen liittyvän yhteiskunnallisen odotushorisontin muuttamisen kautta. Emme siis lue Benjaminin Taideteos-esseetä ensisijaisesti yleiskuvauksena taiteen ja tekniikan suhteesta, vaan tietyssä historiallisessa tilanteessa tehtynä yrityksenä ajatella uudelleen taiteen yhteiskunnallista ja poliittista ulottuvuutta, jonka muutos taiteentuotannon tekniikoissa on tehnyt mahdolliseksi (tällaisesta luennasta tarkemmin ks. Leslie, 1997; 2000; 2003).

Tutkimme Benjaminin "toiseksi tekniikaksi” kutsumaa suhdetta taiteen ja poliittisen liikehdinnän välillä tarkastelemalla sen empiiristä viitepistettä, 1920-luvun avantgardistista ${ }^{1}$ taidetta, jonka Benjamin todisti henkilökohtaisesti ja myös kirjoitti siitä paljon (Benjaminin ajattelun avantgarde-kontekstista yleisesti ks. esim. Schwartz, 2001; Lindroos, 1998, s. 144-148). Käsittelemme erityisesti kahta Benjaminin mainitsemaa esimerkkiä. Ensimmäinen 
on 1920-luvun neuvostoliittolainen konstruktivistinen elokuva, erityisesti Dziga Vertovin äänielokuva. Toinen on 1920-luvun Weimarin tasavallan arkkitehtuurikulttuurissa paljon puhuttanut utopia lasirakentamisesta.

Artikkelin ensimmäisessä osassa käymme läpi Benjaminin esseen keskeiset piirteet ja korostamme, että Taideteos-esseen vähemmän tunnettu toinen versio avaa useita epäselvyyksiä, joita Benjaminin Taideteos-esseeseen on tyypillisesti liitetty. Keskitymme erityisesti tässä versiossa esitettyyn ajatukseen taiteen "toisesta tekniikasta”. Tämän jälkeen pohdimme kahden tapausesimerkin, elokuvan ja arkkitehtuurin, kautta 1920-luvun avantgarden kulttuuripolitiikan tavoitteita ja sen suhdetta Benjaminin käsitteellistämään "toiseen tekniikkaan".

\section{Taideteos-esseen}

\section{vallankumouksellinen taidepolitiikka}

Benjaminin Taideteos-esseen tulkitseminen on haastavaa siksi, että tekstillä voi nähdä olevan kaksi eri tavoitetta. Näistä ensimmäinen ja paremmin tunnettu on taidefilosofinen ajatus taideteoksen auran muuttumisesta. Benjamin pyrkii esseessään tunnetusti osoittamaan, että teollisten uusintamistekniikoiden kehittymisen myötä taideteoksen ainutkertaista etäisyyttä vastaanottajaan ja auktoriteettia suhteessa omaan syntyhistoriaansa, tekijäänsä ja paikkaansa ilmaiseva "aura" muuttuu ongelmalliseksi.

Benjamin tarkastelee Taideteos-esseessään kysymystä aurasta osana yhteiskunnallisen ja kokemuksellisen rakenteen historiallista muutosta (Elo, 2008, s. 211-212). Tämän vuoksi auran olemassaolo tai sen väitetty "katoaminen" on hyvin moniselitteinen asia. Usein asiaa yksinkertaistetaan ja väitetään Benjaminin esittäneen, että aura yksiselitteisesti katoaa noin 1900-luvun alussa, kun taideteoksia aletaan valmistaa yhä enemmän teollisten menetelmien kautta. Benjaminin mukaan aura ei kuitenkaan varsinaisesti ole koskaan kuulunut taideteokseen sellaisenaan, vaan se ilmaisee historiallisesti ennen kaikkea käsitystavan, jossa teosta voidaan pitää "aitona”, ja tämä käsitys syntyy moninaisten yhteiskunnallisten, tiedollisten ja kokemuksellisten tekijöiden yhdistelmästä. Benjamin pitää siten taiteen aitoutta nimenomaan historiallisena ja muuttuvana määreenä, ei ylihistoriallisena kriteerinä. ${ }^{2}$ Teknisen uusinnettavuuden aikakausi ei siis sinänsä merkitse auran katoamista, vaan pikemminkin tekee aidon ja kopion välisestä erottelusta eräässä mielessä epäolennaisen.

Tästä päästään Taideteos-esseen toiseen tavoitteeseen: essee näyttää jakavan samankaltaisia poliittisia tavoitteita, kuin mitä erityisesti avantgardessa on kehitetty. Elokuvatutkija Miriam Hansenin sanoin työttömien ja köyhtyneiden urbaanien massojen kriisitilanne, taiteen uusintamistekniikoiden ja -välineiden objektiivinen kehitys sekä taiteen pyrkimysten ja estetiikan uudelleenarviointi, jota avantgarde-liikkeet kuten dada ja surrealismi edustavat, osuvat Benjaminin aurateesin kanssa historiallisesti yksiin (Hansen, 1987, s. 183). Tässä tilanteessa aukeaa myös mahdollisuus uudelleen määrittää taiteen merkitys ja käyttökontekstit. Tämä pyrkimys on lähtökohtaisesti poliittisesti sitoutunut ja sijoittuu pääosin taideteoksen olemusta pohtivan taidefilosofisen kysymyksenasettelun ulkopuolelle.

Tätä puolta korostaa myös tekstin julkilausuttuna tavoitteena oleva pyrkimys muotoilla ohjelma taiteen politisoinnille, joka Benjaminin mukaan on kommunistinen pyrkimys, erotuksena fasistisesta pyrkimyksestä estetisoida politiikka. Etsiessään vastavoimaa 1930-luvun fasistiselle kulttuuripolitiikalle, Benjamin ei kuitenkaan kirjoita teoriaa taiteen propagandistisesta käytöstä kapeassa mielessä, vaan tarkastelee laajemmin ihmisjoukkojen ja taiteen välistä suhdetta uusien tekniikoiden avaamista mahdollisuuksista käsin. Tämä tavoite aloittaa ja lopettaa Taideteos-esseen. Johdannossa Benjamin ilmoittaa tavoitteekseen kehittää käsitteitä, joita voidaan käyttää "vallankumouksellisten vaatimusten muotoilemiseen taidepolitiikassa" (Benjamin, 1989, s. 140). Tekstin loppuosassa tämän hankkeen tärkeys ilmenee tavoitteena "vastustaa politiikan estetisointia politisoimalla taide" (Benjamin, 1989, s. 167, käännöstä muutettu). 
Taideteos-esseen taidefilosofisen sekä sen poliittisen tavoitteen välinen yhteys voi vaikuttaa hämmentävältä, sillä Benjamin ei yhdistä niitä systemaattisesti. Osittain tulkitsemisen vaikeus juontuu myös tekstin eri versioiden monivaiheisesta julkaisuhistoriasta. Benjamin ei saanut saksankielistä versiota esseestään julkaistua elinaikanaan, vaikka työsti siitä kolme eri versioita vuosina 1935-1939. Hän näki esseensä julkaistuna vain Pierre Klossowskyn ranskannoksena, joka ilmestyi lyhennettynä ja vahvasti toimitettuna Frankfurtin koulukunnan Zeitschrift für Sozialforschung -lehdessä vuonna 1936. Tästä versiosta poliittiset viitepisteet poistettiin, muun muassa yllämainitut alku- ja loppusanat poistettiin kokonaisuudessaan. Tämän lisäksi yksittäistä sanastoa muokattiin ja esimerkiksi 'fasismi' muuttui 'totalitarismiksi'.

Tekstin tunnetuin versio on vuonna 1939 tehty niin sanottu kolmas versio (dritte Fassung). Tässä muodossa Taideteos-essee on sisällytetty Benjaminin koottujen teosten, Gesammelte Schriftenin, ensimmäiseen osaan ja se kuuluu myös reseptiohistoriallisesti tärkeimpiin käännöksiin, kuten lluminations-kokoelmaan ja suomennokseen Messiaanisen sirpaleita -kokoelmassa.

Vaikka kolmas versio on vakiintunut, niin Benjamin itse toivoi tekstistä julkaistavaksi alkuvuodesta 1936 päivättyä versiota (Benjamin, 1991b, s. 661). Tämä versio tunnetaan nykyisin tekstin toisena versiona (zweite Fassung) ja se löydettiin vasta 1980-luvulla Benjaminin koottujen teosten toimitustyön yhteydessä. ${ }^{3}$

Erityisesti Esther Leslie on kuvannut näiden versioiden eroavaisuudet. Pääpiirteittäin erona on se, että toisessa versiossa taiteen teknistymisen poliittinen merkitys korostuu (Leslie, 2000, s. 256). Leslie esittää, että käsitellessään uusien havainnon ja tiedon muotojen syntyä uusista tekniikan ja taiteen yhteyksistä Benjamin kommentoi läntisessä marxilaisuudessa paljon käsiteltyä esineellistymisen (reifikaatio) ja vallankumouksellisen subjektiviteetin välistä problematiikkaa. Tämän teeman keskeisin ja samalla myös paljon kiistelty teksti on Georg Lukácsin Geschichte und Klassenbewußtsein (1923). Teoksessaan Lukács pyrkii ratkaisemaan työläisten järjestäytymisen kysymyksen kommunistisen puolueen massoille antaman luokkatietoisuuden kautta. Lukácsin mukaan massojen tai proletariaatin tietoisuus itsestään, omasta asemastaan ja mahdollisuudesta järjestäytyä ajamaan omaa etuaan jääkin aina vajavaiseksi, ellei puolue anna sille "lisättyä luokkatietoisuutta” (zugerechnete Bewusstsein). Lukácsin teorian seuraukset ovat kuitenkin Leslien mukaan Benjaminille poliittisesti epätoivottuja, sillä tässä mallissa työläismassat lamaantuvat ja jäävät odottamaan ulkoapäin annettua tietoisuutta, ilman mitään itsenäistä roolia tässä prosessissa. (Leslie, 2000, s. 157.)

Benjamin sen sijaan ajattelee juuri mekaanisesti uusinnettavien taidemuotojen tarjoavan mahdollisuuden kehittää sellaista vallankumouksellista kykyä, joka ei lamauta ihmisiä passiivisiksi toimijoiksi odottamaan ylhäältäpäin tulevia ohjeita. Vaikka tietyillä yksilöillä, kuten erityisesti ajatus taiteilijoista etuvartiona (avantgarde) vihjaa, on tämän vauhdittamisessa tärkeä rooli, niin lopulta vain ihmisten oma aktiivisuus ja yhteenliittyminen voi Benjaminin mukaan aiheuttaa poliittisen muutoksen.

On tärkeää huomata, että Benjamin myös tunnistaa tähän liittyviä uhkakuvia, toisin kuin esimerkiksi Richard Wolin (1994) Benjamin-kritiikissään esittää. Wolinin mukaan todellisuudessa esimerkiksi elokuvaa ja radiota sovellettiin parhaiten juuri niissä totalitaristisissa projekteissa, joita vastaan Benjamin katsoi niiden muodostuvan. Wolinin väite on toki osittain täysin oikea: massojen kiihdyttämisellä esimerkiksi elokuvien kautta on ollut historiallisesti myös hyvin kohtalokkaita seurauksia. Mutta väite, että Benjaminin esitys mitätöityisi tällä perusteella on ongelmallinen. Itse asiassa Benjamin ennakoi tällaista kritiikkiä ja vastaa siihen tekstikatkelmassa Luokkatietoisuudesta (Benjamin, 2014a, s. 206-207). Tekstissä, joka oli alun perin alaviite Taideteos-esseen toiseen versioon, Benjamin vastustaa aikansa massapsykologista kuvausta väkijoukoista, joista tunnetuin on Gustave Le Bonin teos Psychologie des foules (Joukkosielu). Le Bonin mukaan massojen konstituution taustalla on aina jonkinlainen irrationaalinen ainesosa, joka on potentiaalises- 
ti hyvin vaarallinen jopa itselleen. Tätä vasten Benjamin selvittää tarkemmin mitä hän itse tarkoittaa väkijoukolla/massalla tässä yhteydessä. Ensinnäkin Benjamin varoittaa tulkitsemasta massojen rakennetta yksinkertaisesti tiiviin ykseyden näkökulmasta. Massa ei siis tarkoita samaa kuin ykseys. Le Bonin kaltaiset massapsykologiset tulkinnat massojen vaarallisuudesta eivät Benjaminin mukaan näe sitä, että massoissa kyse ei ole tiiviistä yksimielisyydestä vaan moninaisten mielipiteiden yhteenliittymästä.

Juuri ihmisten tuleminen yhteen, ei samanmielisyys, on "vallankumouksellisen taidepolitiikan" kehittämisen keskeisin lähtökohta. Benjamin tunnisti aikansa uudet taidemuodot tärkeiksi juuri siksi, että ne loivat uusia ja tehokkaampia yhteenliittymisen tapoja. Esimerkiksi elokuva ei ole siis vain propagandistinen väline tiheän ja kaikesta samaa mieltä olevan massan kiihdyttämiseen, vaan se on pikemminkin mediumi, joka tuo erilaiset sosiaaliset suhteet yhteen, mutta ei vielä vääjäämättömästi määritä mitä tästä yhteenliittymästä syntyy.

Benjaminin vallankumouksellinen taidepolitiikka painottaa siis samanaikaisesti elämän realiteetteja 1930-luvun Euroopassa, mutta se panee samalla painoa modernin elämän "mediaalisuudelle" vallankumoukselliseksi tulemisessa. ${ }^{4}$ Esimerkiksi elokuva ei Benjaminille ensisijaisesti merkitse esitystä "erilaisesta" elämästä, vaan elokuvateatterissa tapahtuvaa kollektiivin yhteentulemista. Taiteen teknisen uusinnettavuuden ja massojen välistä suhdetta määrittää Benjaminin mukaan erityinen suhde, jota hän luonnehtii "toiseksi tekniikaksi".

\section{Avantgarden kulttuuripolitiikka ja taiteen toinen tekniikka}

Miksi sitten juuri kysymys taiteen tekniikoista, eikä taiteesta yleisesti, on tässä yhteydessä niin olennainen? Kysymyksen ymmärtämiseksi on syytä palata Taideteos-esseen vuoden 1936 toiseen versioon, erityisesti sen VI-lukuun, jossa taiteen tekniikoiden ja väkijoukkojen välistä suhdetta pyritään ajattelemaan uudella tavalla.

Tekniikan ja massojen uusi suhde 1920-luvun avantgarden kontekstissa, merkitsee Benjaminille "toista tekniikkaa", joka eroaa siitä, mitä Benjamin kutsuu "ensimmäiseksi tekniikaksi”. Ensimmäinen tekniikka on Benjaminin mukaan mahdollista vain hyvin rajatulle osaa ihmisistä. Esimerkiksi kuvanveistäjien käyttämä tekniikka vaatii erityisiä työkaluja, materiaaleja ja koulutusta. Sitä myös usein tukee jonkinlainen myytti, joka nostaa taiteilijan erityisasemaan. Olennaista on siis se, että tämä tekniikka kuuluu vain harvoille, siis niille jotka ottavat sen avulla esimerkiksi (ihmis)luonnon materaalina "hallintaansa". Käänteisesti tätä taitoa vailla olevat massat ovat taiteen todistajina sekä katsojina etäännytetty tästä prosessista.

Sen sijaan Benjaminin hypoteesi taiteen "toisesta tekniikasta" nostaa esiin yksilöiden sijaan yhteenliittymät korostamalla yksilöllisen suorituksen sijaan sosiaalisia suhteita sekä yhteenliittymiä työn ja tuotannon lähtökohtana. Tästä murroksesta kumpuaa myös Benjaminille ominainen tekniikan ja emansipaation välisen mahdollisuuden ajatteleminen:

Ensimmäinen tekniikka suuntautui todellakin luonnon hallintaan, toinen tekniikka sen sijaan paljon enemmän luonnon ja ihmiskunnan väliseen yhteispeliin. Nykyisen taiteen yhteiskunnallisesti ratkaiseva tehtävä on harjaannuttaminen tähän yhteispeliin. Tämä pätee erityisesti elokuvasta. Elokuva palvelee ihmisen harjaantumista sellaisiin havaintoihin ja reaktioihin, joita määrittää toiminta välineistön kanssa - välineistön, jonka merkitys hänen elämässään kasvaa liki päivittäin. Toiminta tämän välineistön kanssa opettaa hänelle samalla, että vasta sitten kun ihmiskunnan perusrakenne on mukautunut niihin uusiin tuotantovoimiin, jotka toinen tekniikka on paljastanut, hänen ei enää tarvitse olla välineistön renki vaan hän voi vapautua sen avulla. (Benjamin, 2014b, s. 28.)

Avantgarden historiallinen merkitys on tässä keskeinen (Benson, 2010). Moniselitteisen ja monivivahteisen avantgarden historiasta, tavoitteista ja merkityksestä kiistellään edelleen, mutta tässä yhteydessä sen merkitys kiteytyy ennen kaikkea siihen, että se kehitti sellaista 
käsitystä taiteesta, joka kumosi korkeaan osaamiseen ja koulutukseen perustuvan työnjaon ja korvasi tämän suhteilla, joissa tekijän ja katsojan välinen suhde ja osallisuus määritellään uudella tavalla. Tällainen käsitys osallisuudesta on myös Benjaminin mukaan väistämätön emansipatoristen vaateiden esittämisen kannalta:

Mitä enemmän kollektiivi näet omaksuu toisen tekniikkansa, sitä selvemmin tuntevat siihen kuuluvat yksilöt, kuinka vähän he ovat tähän saakka, ensimmäisen tekniikan vallassa, päässeet osallisiksi siitä mikä heille kuuluu. Kyseessä on toisin sanoen ensimmäisen tekniikan mitätöimisen kautta vapautunut yksilö, joka esittää vaatimuksensa. (Benjamin, 2014b, s. 29.)

Minkälaisista taidemuodoista taiteen "toisessa tekniikassa" sitten on kysymys? Keskitymme seuraavassa erityisesti kahteen taidemuotoon, joille Benjamin antaa Taideteos-esseessä erityistä painoarvoa siksi, että ne perustuvat sekä teknisen uusinnettavuuden tarjoamiin mahdollisuuksiin että laajempaan kulttuuripoliittiseen pyrkimykseen ajatella taiteen yhteiskunnallista roolia. Nämä taidemuodot ovat Benjaminin mukaan elokuva ja moderni arkkitehtuuri (Benjamin, 1989, s. 164).

\section{Filmin konstruktivismi ja äänielokuvan kysymys}

Elokuva on Benjaminille kiistatta tärkein taidemuoto, jonka myötä taiteen toinen tekniikka tulee esiin. Modernin elokuvan piirissä erityisesti avantgarde Venäjällä edustaa Benjaminille mahdollisuutta saada poliittisen massaliikkeen vaatima perspektiivi esiin, sillä se kääntää huomion utooppisesta ja etäisestä arkipäiväiseen ja lähelle (Lindroos, 1998, s. 156.). Käsittelemme jatkossa Dziga Vertovin tuotantoa, joka ehkä parhaiten edustaa tätä pyrkimystä.

Vertovin elokuvat osuvat ratkaisevaan vaiheeseen neuvostoliittolaisessa kulttuuripolitiikassa. Lokakuun vallankumouksen jälkeen aina 1920-luvun puoliväliin asti Neuvostoliiton kulttuuripolitiikka hyväksyi kokeellisen taiteen osaksi poliittista projektia. Avantgarden tehtävänä oli kyllä myös poliittisen viestin välittäminen, mutta sen lisäksi porvarillinen taideinstituutio pyrittiin tarkoituksellisesti haastamaan tukemalla valtiollisesti kokeellisia taiteita. (Hicks, 2007, s. 8-9.)

Tässä kulttuuripoliittisesti kokeelliselle avantgardelle suotuisassa ilmastossa toiminut Vertov kuului konstruktivististen taiteilijoiden sisäpiiriin, jossa esikuvaksi nostettiin hyödyllisiä esineitä tuottava insinööri ja sosialistisen yhteiskunnan rakentaminen. Erityisen voimakkaasti Vertov vastusti "teatterillisia" illuusioita, kuten ajan ja paikan jatkuvuutta sekä henkilöhahmojen psykologisen syvyyden vaikutelmaa. Elokuviaan Vertov kuvailee pyrkimyksenä elokuva-totuuteen (кино-правда). Тämä saavutetaan tallentamalla mekaanisesti ja ennakoimatta otoksia elämästä sellaisena kuin se on (жызнь как она есть). Elokuva-totuus vaatii kuitenkin myös aktiivista ja subjektiivista otetta, jälkikäsittelyä ja "elokuvan kieliopin” täydellistä hallintaa. (Petriç, 1987, s. 1-5.)

Tämä kahtalaisuus lävistää Vertovin teoksia: uutisfilmien kuvaajana uransa aloittanut Vertov pyrkii kaikissa 1920-luvun töissään kuvaamaan ennakoimattomia tilanteita yllättävillä tavoilla ja muokkaa näistä aineksista jälkikäsittelyssä omaleimaisia taide-elokuvia. Yhtäältä hänen elokuvansa ovat siis läpinäkyvästi teknisiä, konstruoituja, toisaalta ne keskittyvät jokapäiväiseen. Tästä hyvä esimerkki on Vertovin kuuluisin elokuva Mies ja elokuvakamera (1929). Se on käytännössä montaasi- ja trikkitekniikoiden käsikirja, jossa mikään ei ole "luonnollista". Kuitenkin sen aihe, elokuvaaja työssään tallentamassa neuvostoliittolaisen kaupungin päivää, ihmisten työtä ja huveja, on helposti käsitettävä. (Michelson, 1984, s. xxv-xl.)

Benjamin tutustui Vertovin elokuviin oletettavasti Moskovassa talven 1926-1927 aikana. Palattuaan Saksaan hän kirjoitti artikkelin Zur Lage der russischen Filmkunst, jossa hän kiittää Vertovin elokuvaa Maailman kuudennes naamioiden poistamisesta: Vertov hylkää näyttelemisen ja filmaa kohteitaan juuri silloin kun nämä eivät sitä odota (Benjamin, 2004, s. 213). Myös Taideteos-esseessä Vertovin vaikutusta 
lienee esimerkiksi Benjaminin huomio, jonka mukaan "elokuvassa on paljon vähemmän merkityksellistä, että esittäjä esittää yleisölle jotain toista [kuin mitä hän on], kuin se, että hän esittää laitteistolle itseään” (Benjamin, 1991b, s. 366; vrt. Benjamin, 1989, s. 152).

Erityisesti Taideteos-esseen toisen version XI- ja XII-luvut keskittyvät käsittelemään tekijyyden muutosta elokuvassa ja huipentuvat yllä käsiteltyyn alaviitteeseen luokkatietoisuudesta. Näissä luvuissa Benjamin linjaa, että "laitteiston avulla tehdyissä representaatioissa ihmisten vieraantuneisuus itsestä [Selbstentfremdung] on johtanut erittäin hyödylliseen käyttöön" (Benjamin, 1991b, s. 369)5. Luokkatietoisuusalaviitteen valossa tätä voi tulkita tiiviin massan purkamiseksi ja poliittista prosessia hyödyntäväksi differentaatioksi. Vertovilaisen "elokuva-totuuden" kannalta kysymystä voi ajatella uutisfilmin luoman yhteisön ja montaasitekniikalla toteutetun filmin mahdollistamana uutena yleisösuhteena. Tällainen elokuva käytännöllisesti sisältää mahdollisuuden estää yleisön tiivistyminen kohti yksimielistä, mutta Benjamin mukaan taantumuksellista joukkoa, jota Le Bon ja muut massapsykologit kuvaavat (Benjamin 2014, s. 206-207; ks. myös Lindroos 1998, s. 156).

Vertovin elokuvista vuonna 1930 valmistunut Entusiasmi - Donbassin sinfonia ansaitsee Taideteos-esseen valossa erityishuomion. Kyseessä on Vertovin ensimmäinen äänielokuva, ja erityisen mielenkiintoisen siitä "toisen tekniikan” näkökulmasta tekee se, että tämä teos koskettaa suoraan ongelmakohtaa, jota äänielokuva Taideteos-esseen kokonaisjäsennykselle merkitsee.

Benjamin on selvillä mullistuksesta, jota äänen tulo elokuvatuotantoon merkitsee. Hän huomioi, että eri kielialueille tuotetut elokuvat ovat paradoksaalisesti riippuvaisempia suurpääomasta ja alttiimpia nationalistisille painotuksille kuin mykkäelokuvat. Näitä kriittisiä huomioita vastaan Benjamin kuitenkin painottaa äänielokuvan potentiaalia ja huomauttaa uusista kansainvälisemmäksi tulemisen tendensseistä (Benjamin 1991b, s. 256-357, vrt. Benjamin 1989, s. 168). Pian Taideteos- esseen kirjoittamisen jälkeen Theodor Adornolle lähettämässään kirjeessä (10. 12. 1938) Benjamin kuitenkin myöntää näkevänsä yhä selkeämmin, että äänifilmiä tulisi tarkastella elokuvateollisuuden operaationa, jonka päämäärä on nujertaa mykkäfilmin vallankumouksellinen vaikutus (Benjamin, 1977, s. 140).

Ongelma asettuu seuraavasti: ensinnäkin Benjaminin omat aavistukset äänifilmiin liittyvistä vaaroista osoittautuivat historiallisesti todellisiksi, ja esimerkiksi Vertov joutui luopumaan kunnianhimoisista projekteistaan stalinistisen kulttuuripolitiikan aikana 1930-luvulla. Lähestyttäessä toista maailmansotaa kansalliset elokuvatuotannot muuttuivat selvästi nationalistisemmiksi, ja Hollywoodin tähtikultti, jota Adorno 1930- ja 1940-luvun töissään analysoi, johti elokuvateollisuutta selvästi taantumukselliseen suuntaan, mikäli sitä tarkastellaan Benjaminin vallankumouksellisen taidepolitiikan projektin näkökulmasta. Kuitenkaan Taideteos-esseen julkaistut versiot eivät onnistu ratkaisemaan tätä ongelmaa, vaan ainoastaan melko vaisusti tunnustavat sen olemassaolevaksi. Koska elokuvaa muuten käsitellään vallankumouksellisen taidepolitiikan tärkeimpänä taidemuotona, Benjamin näyttää kirjoittavan itsensä ristiriitaan.

Esseen muistiinpanot kuitenkin tuovat lisätekijän ongelmanasetteluun. Niissä Benjamin tarkastelee äänielokuvaa "toisen tekniikan" kannalta. Hän kirjoittaa ääninauhan "likvidoivan taustamusiikin ongelman”. Tämä tarkoittaa sitä, ettei äänestä enää kysytä "mistä" se on peräisin, kuten mykkäelokuvan säestyksen kohdalla, vaan "mitä" se on: iskelmä tai Beethovenin sonaatti voidaan yhtäläisesti asentaa (einmontieren) osaksi elokuvaa. Jos mykkäelokuvassa musiikki "odotti oven ulkopuolella”, äänielokuvassa ääni saa uuden funktion. (Benjamin, 2012, s. 253.) Tässä hahmotuksessa ääni saa itsellisen aseman suhteessa kuvaan, aivan kuten mykkäfilmissä kuva saavuttaa itsellisen aseman suhteessa kuvattuun kohteeseen.

Mikäli Benjaminin alustavaa ajatusta äänen itsellisyydestä tarkastellaan Vertovin tuotannon kannalta, huomio kääntyy Entusiasmiin. On kuitenkin syytä korostaa, että luenta on speku- 
latiivinen, se ei perustu Benjaminin esittämille näkemyksille tästä elokuvasta. Ei ole tiedossamme, että Benjamin olisi kommentoinut tai nähnyt Entusiasmia, ja aiheen kattava käsittely vaatii jatkotutkimusta. Jatkossa tematisoimme Taideteos-esseen äänielokuvaa koskevan teoreettisen ristivedon tuomalla sen alustavasti dialogiin Entusiasmin kanssa.

Entusiasmi on raskaan teollisuuden ensimmäisiä uskottavia elokuvadokumentteja ja nauhotettu kentällä. Vertov kuvasi ensimmäisen viisivuotissuunnitelman kunniaksi toteutetun elokuvan Neuvosto-Venäjän teollisessa sydämessä, Donetskissa. Kuvauskohteista varsinkin hiilikaivos ja teräsmasuunit on tallennettu vaikuttavasti. Elokuvan ääniraita pyrkii Vertovin mukaan organisoimaan äänen kuten kuvan. Hän viittaa elokuvaan nimillä "melusinfonia" ja “äänimarssi” (Vertov, 1984b). Elokuvassa kuullaan myös musiikkia ja työläisten puheita, mutta suurimman huomion saa raskaan teollisuuden äänekäs melu. Sen kuva- ja äänikompositio kuvaa edistyksen liikettä tsaarinajasta (ääninä kirkonkellot, resuisen köyhälistön julkijuopottelu ja rähinä) sosialistiseen nykyisyyteen (ääninä koneiden pauhu ja pioneerien marssit). Vastakkainasettelu puretaan proletariaatin voitoksi, jonka merkkinä kajahtaa Internationaali.

Entusiasmin narratiivisuutta voi Vertovin elokuvaestetiikan puitteissa pitää konventionaalisena, minkä selittää mahdollisesti osaltaan elokuvan syntykonteksti (Michelson, 1984, s. 327). Elokuvan tekohetkellä konstruktivistien ja puolueen hetkellisesti jakama ajatus kokeellisen muodon ja poliittisen edistyksen liitosta oli täysin mennyttä, ja Entusiasmista tuli 1920-luvun avantgarden joutsenlaulu. Elokuva joutui heti valmistuttuaan epäsuosioon ja jo aiemmin "formalismista" syytetty ja kiistanalainen ohjaaja joutui vetäytymään julkisesta elämästä. Vertov palasi uutisfilmien leikkaamoon. Sosialistisen realismin nousu ja poliittinen lahkolaisuus tappoivat tai painoivat maan alle kaiken muunkin uutta luovan ja kriittisen kulttuuritoiminnan. (Michelson, 1984, s. lvii-lxi.)

Tämä tilannekuvaus on syytä pitää mielessä, kun otetaan esiin Vertovin näkemys Entusiasmista "kuvan ja äänen monimutkaisena vuoro- vaikutussuhteena" (Vertov, 1984a, s. 114). Elokuvan ääniraita ilmaisee jotakin, mitä tuon ajan poliittisessa ilmastossa olisi tuskin voinut kuvin kertoakaan: Entusiasmissa äänen välitön, elementaarinen voima horjuttaa sanoin ilmaistua poliittista viestiä. Produktivistinen propaganda, johon elokuvan puheosuudet eittämättä osallistuvat, häviää koneiden pauhulle, ja eräässä mielessä tämä Vertovin viimeiseksi jäänyt kokonaisjäsennys koneen ja ihmisen liitosta näyttää pikemminkin väkivaltaiselta dystopialta kuin harmoniselta utopialta (Kahn, 2001, s. 143). ${ }^{6}$

Entusiasmin tarkasteleminen suhteessa Benjaminin osin ristiriitaisilta vaikuttaviin huomioihin äänielokuvasta voidaan tiivistää kahteen huomioon. Ensinnäkin Vertovin "melusinfonia" todistaa, ettei äänielokuva jäännöksettä samastu esimerkiksi nationalistiseen propagandaan, joita Benjamin ja Vertov vastustavat. Itse asiassa ääninauhan itsellisyydessä voidaan kuulla merkittävä vastavoima ja protesti tätä kehitystä vastaan. Toiseksi on huomioitava, että Benjaminin tasapainotteleva kirjoitustapa tavoittaa kuitenkin hyvin aikansa todelliset valtasuhteet. Vertovin projekti on ehdoton poikkeus 1930-luvun äänielokuvatuotannossa, joka pääsääntöisesti kehittyy teatterillisen melodraaman suuntaan. Suhteessa vallankumouksellisen taidepolitiikan ohjelmaan voidaan sanoa, että äänielokuvaan sisältyvä mahdollisuus "toisen tekniikan" ulottamiseen visuaalisesta auditiiviseen osatekijään ei kirjoitushetkellä suinkaan ollut hegemoninen projekti. Entusiasmi kuitenkin tuo esiin, että tuotannon arkipäiväiset äänet voidaan ymmärtää massojen elämää koskettavana elementtinä, jonka kanssa näiden on yleisönä tultava tekemisiin.

\section{Lasiarkkitehtuurin yhteiskunnallinen läpinäkyvyys}

Elokuvan tavoin myös ensimmäisen maailmansodan jälkeinen uusi arkkitehtuuri (Neues Bauen) ilmaisee laajempaa avantgardistista pyrkimystä yhdistää tekniset innovaatiot yhteiskunnalliseen emansipaatioon. Benjamin ei kirjoita siitä yhtä paljon kuin elokuvasta, mutta 
arkkitehtuurilla on tästä huolimatta keskeinen asema Benjaminin ajattelussa ainakin kahdesta syystä. Ensinnäkin arkkitehtuuri on lähtökohtaisesti kollektiivinen taidemuoto, joten sillä on korostetusti yhteiskunnallisia ulottuvuuksia. Toiseksi arkkitehtuuri on sidoksissa saatavissa oleviin materiaaleihin sekä vallitseviin rakennustekniikoihin, joten se tulee ymmärrettäväksi vain suhteessa tietyn aikakauden laajempiin tuotantotapoihin kuten Benjamin Taideteosesseessään esittää.

Benjamin oli erityisesti kiinnostunut 1920-luvun lasiarkkitehtuuriin liittyvistä emansipatorisista mahdollisuuksista (Benjamin, 2014a, s. 78). Lasiarkkitehtuuri on monella tapaa Benjaminin aikalaiskontekstin, Weimarin tasavallan lyhyen ajanjakson (1919-1933) tuote. Erityisesti taiteen ja kulttuurin suhteen Weimarin tasavaltaa pidetäänkin usein neuvostoliittolaisen avantgarden tavoin tärkeänä kokeellisena aikakautena. Tämä pätee myös lasiarkkitehtuuriin, joka oli eräs Weimarin aikakauden arkkitehtuurin tärkein keskustelunaihe (Ward, 2001 s. 45-91). Kyseinen keskustelu koski juuri lasiarkkitehtuurin liittyvää potentiaalia toimia erityisesti demokraattisemman, jopa sosialistisen, yhteiskunnan välineenä. On myös syytä pitää mielessä, että tämä 1920-luvun keskustelu on luonteeltaan hyvin erilaista kuin myöhempi 1900-luvun jälkipuoliskon lasiarkkitehtuuri esimerkiksi pilvenpiirtäjissä, joka on leimallisesti ollut luonteeltaan ainoastaan yhteiskunnan eliitin estetiikkaa. Käsittelemme tässä lasiarkkitehtuuria siis ainoastaan tämän spesifin Weimarin kontekstin kautta, joka nykynäkökulmasta kuulostaa luonnollisesti hieman erikoiselta. ${ }^{7}$

Weimarin aikakauden arkkitehtien tavoin Benjamin katsoi 1920-luvun arkkitehtuurissa käytetyn lasin olevan enemmän kuin pelkkä materiaali. Tälle syvemmälle materiaalikäsitykselle Benjamin löysi tarkoitukseensa sopivan muotoilun ennen kaikkea arkkitehtuurihistorioitsija Sigfried Giedionin ajatuksesta, että rakennusmateriaaleilla on myös "alitajunnan rooli” (Benjamin, 2014a, s. 46). Tällä Giedion oli tarkoittanut sitä, että voimme nähdä materiaalivalinnoisssa myös laajempia yhteiskunnallisia kehityskulkuja ja siihen liittyviä tiedosta- matta tehtyjä valintoja. Esimerkiksi teoksessaan Bauen in Frankreich, Bauen in Eisen, Bauen in Eisenbeton (1928) Giedion korostaa, että uusi arkkitehtuuri, joka perustuu materiaalisesti erityisesti teräksen, betonin ja lasin yhteenliittymään, on ajateltava ennen kaikkea vanhasta elämänmuodosta ja sen materiaalisista olosuhteista konkreettisesti vapauttavana. Tätä havaintoa painotti kirjaimellisesti myös Giedionin seuraavana vuonna julkaistu tutkielma Befreites Wohnen samasta aihepiiristä. Materiaalivalintoja perusteltiin siis esimerkiksi käytettävyydellä ja kestävyydellä, mutta näiden takana oli vielä alitajuntamainen laajempi ajatus yhteiskunnallisesta tasavertaisuudesta ja historiallisista jännitteistä vapautumisesta.

Giedionin tulkinta sopii varsin hyvin yhteen sen kanssa, mitä myös Benjamin esitti myöhemmin Taideteos-esseessään 1930-luvun puolivälissä. Myös ennen tätä hän oli kirjoittanut uusien rakennusmateriaalien suhteesta ensimmäisen maailmansodan jälkeiseen yhteiskunnalliseen tilanteeseen erityisesti esseessään Kokemus ja köyhyys (1933) jota edelsi lyhyt katkelma ensimmäisen maailmansodan jälkeisestä destruktiivisesta luonteesta esseessä Der destruktive Charakter (1931).

Kiinnostus lasiin eräänlaisena uutena, vapauttavana ja vanhan puhdistavana materiaalina sijoittuu ennen kaikkea viimeistään ensimmäisestä maailmansodasta alkaneeseen kulttuuriseen murrokseen. Benjamin luonnehtii tätä murrosta destruktiivisuuden ja kokemuksen köyhyyden käsitteillä. Kyseiset käsitteet eivät kuitenkaan tarkoita Benjaminille mitään merkityskatoa, josta tulisi olla huolissaan, vaan pikemminkin uutta, aurasta vapaan kokemuksen mahdollisuutta: "lasiesineillä ei ole minkäänlaista auraa", kuten Benjamin esitti (Benjamin, 2014a, s. 137; ks. tästä myös Mertins, 1996). Esseessään Der destruktive Charakter (GS4, s. 396-398) Benjamin kuvaa suurkaupunkilaisen luonteen. Tällaisella luonteella on Benjaminin mukaan lähes pakottava tarve murtautua ulos vanhoista sosiaalisista ja kulttuurisista muodoista ja tehdä tilaa uudelle. Sen keskeisin periaate on siis perinteen hylkääminen.

Ajatus destruktiivisuudesta näkyy myös ark- 
kitehtuurissa katkoksena traditioon. Benjamin kuvaa tätä asunnon ja asumisen muuttumisen kautta. Benjaminin mukaan 1800-luvun arkkitehtuurille ja sisustussuunnittelulle leimallinen pyrkimys kotoisuuteen on rakennettu ainutkertaisten yksityiskohtien varaan: valokuvat seinällä, matkamuistot ja muut koriste-esineet, perityt huonekalut ja niin edelleen ilmentävät pysyvyyttä, jatkuvuutta ja jokaisen kodin erityisyyttä. Benjaminin työn keskiössä oleva moderni ihminen, jolle ensimmäinen maailmansota oli tarkoittanut väistämätöntä katkosta tästä jatkuvuudesta sekä konkreettisesti rintamalla että myöhemmin 1920-luvun suurkaupunkien aistiärsykkeiden tulvassa, kokee kuitenkin jatkuvaa vieraantuneisuuden tunnetta tällaisessa asunnossa. Hänen mukaansa kaikki tällaisen kotoisuuden ("plyysikamarin") elementit tuntuvat julistavan, että "tänne sinulla ei ole mitään asiaa" (Benjamin, 2014a, s. 137-138). Kuten Benjaminin edellä lainattu elokuvaa koskeva muistiinpano kuitenkin paljastaa, hänelle vieraantuneisuus on uuden, "köyhän" kaupunkilaiskokemuksen oleellinen ainesosa, johon massojen on harjaannuttava.

Destruktiivisuus ensimmäisen maailmansodan jälkeisenä vallitsevana kokemuksena ei kuitenkaan merkinnyt ainoastaan perinteisen arkkitehtuurin hylkäämistä vaan ennen kaikkea uuden keksimistä. Tämän ymmärtämisessä kannattaa muistaa edellisessä luvussa kuvattujen konstruktivistien vaikutus erityisesti saksalaisiin arkkitehteihin. Esimerkiksi juuri Benjaminin siteeraama Giedion luonnehti usein konstruktivismia synonyymiksi eurooppalaiselle modernismille (Mumford, 2002). Perinteen hylkäämisen ohella tilalle oli siis myös kehitettävä uusi muotokieli, joka sopisi paremmin sellaiseen elämänmuotoon, jonka Benjamin oli kuvaillut destruktiivisuuden käsitteen kautta. Tässä keskeisessä asemassa olivat juuri uudet rakennusmateriaalit, jotka mahdollistavat jatkuvuuden ja ainutkertaisuuden sijaan liikkuvuuden ja anonymiteetin, uuden positiivisessa mielessä ymmärretyn 'köyhyyden'.

Esseessään Kokemus ja köyhyys Benjamin kuvaa näitä uusia rakennusmateriaaleja erityisesti Paul Scheerbartin lasiarkkitehtuuriu- topian kautta. Scheerbart esittää teoksessaan Glasarchitektur (1914), utooppisen vision siitä, että jossain kohtaa 1900-lukua valtaosa rakennuksista tullaan rakentamaan lasista. Tällä on Scheerbartin mukaan kauaskantoisia seurauksia: tuleva "lasikulttuuri" tulee muuttamaan myös modernin ihmisen. (Benjamin, 2014, s. 138.) Vaikka Scheerbartin visio on itsessään hyvin scifimäinen, niin Benjamin tulkitsee sen osana samaa ilmiötä kuin mihin esimerkiksi vuonna 1919 perustettu Bauhaus kuului. Tavoitteena on siis uusien teollisesti valmistettavien rakennusmateriaalien kautta luoda destruktiiviselle luonteelle uudenlainen asumismuoto. Benjaminin mukaan "Scheerbart on lasillaan ja Bauhaus teräksellään puuttunut juuri tähän: he ovat luoneet tiloja, joihin on vaikeaa jättää jälkiä" (Benjamin, 2014, s. 138).

Mitä tämä sitten tarkoittaa Taideteos-esseen kahtalaisen tavoitteen - yhtäältä taideteoksen (tai tässä tapauksessa rakennuksen) ainutkertaisuuteen liittyvänä kysymyksenä ja toisaalta siihen liittyvien emansipatoristen tavoitteiden kannalta? Voimme toki ymmärtää uudet rakennusmateriaalit ja niiden kautta rakentuvan uudenlaisen muotokielen suhteessa Benjaminin ajatukseen auran muutoksesta, jonka empiirinen viitepiste on tekninen uusinnettavuus ja sarjatuotanto. Näin voidaan tulkita esimerkiksi edellä mainitun Bauhausin syntymä. On totta, että Bauhausin kenties tärkeimpänä tavoitteena oli standardisoida huonekalujen ja rakennusten sarjatuotanto, poistaa ajatus niiden ainutkertaisuudesta. Myös esimerkiksi Le Corbusierin vaikutusvaltaisessa arkkitehtuurimanifestissa Kohti uutta arkkitehtuuria (1923/2004) keskeisenä ajatuksena on sarjatuotannon tärkeyden korostaminen ja standardisointi irtiottona perinteiseen rakennustaiteeseen.

Mutta uusissa, "aurasta vapaissa" rakennusmateriaaleissa tuntuu olevan yhtä lailla kyse myös uudenlaisesta elämästä ja yhteiskuntamuodosta, kuten Scheerbart esitti. Tämän ymmärtämisessä juuri lasi rakennusmateriaalina on erittäin keskeinen, sillä sen kautta voidaan ajatella samanaikaisesti konkreettista läpinäkyvyyttä, mutta myös laajempaa yhteiskunnallista läpinäkyvyyttä Giedionin kuvaile- 
malla alitajunnan tasolla. Onkin esitetty, että lasiarkkitehtuurin mahdollistama läpinäkyvyys oli 1920-luvulla luonteeltaan sekä konkreettista (literal) että ilmiömäistä (phenomenal) läpinäkyvyyttä (Rowe \& Slutzky, 1963).

Tällaista kahden tason lasin käyttöä, jossa lasin läpinäkyvyys ei palaudu ainoastaan lasiseen fasadiin kuvaavat esimerkiksi Kölnissä Bruno Tautin suunnittelema Glashaus ("lasitalo"), Pierre Chareaun Parisiisin suunnittelema Maison de Verre ("lasitalo") ${ }^{8}$ sekä ennen kaikkea Walter Gropiuksen suunnittelema Bauhausin koulurakennus Dessaussa. Esimerkiksi hahmopsykologi ja taideteoreetikko Rudolf Arnheimin vieraillessa vuonna 1926 valmistuneessa Bauhausin koulurakennuksessa, hän arveli rakennuksen muotokielen johdonmukaisuuden ja "arkkitehtonisen rehellisyyden" tuottavan samanlaisen vaikutuksen myös sen käyttäjien moraaliin (Droste, 2002, s. 122).

Suurin osa ajan johtavista arkkitehdeista julisti tällaisen Arnheimin tunnistaman kaksinaisen vaikutuksen myös suoraksi tavoitteekseen: esimerkiksi Bruno Tautin ympärille muodostui jo vuonna 1919 arkkitehtien kirjeenvaihtoverkosto, jonka tavoitteena oli muiden avantgardeliikkeiden hengessä etsiä arkkitehtuurin keinoin uutta elämänmuotoa. Ryhmittymän nimi, die Gläserne Kette ("lasiketju”), oli samanaikaisesti viittaus ensinnäkin Tautin suunnittelemaan lasirakennukseen uutena tyylisuuntana mutta myös siihen erottamattomasti kuuluneeseen ajatukseen lasiarkkitehtuurista laajemmin uuden aikakauden kristallistaationa (Forgács, 1995, s. 133-134).

Kyseessä ei siis ollut ainoastaan esteettinen irtiotto aikaisempaan muotokieleen, ornamentiikkaan, vaan lasiarkkitehtuurilla oli myös laajempi pyrkimys saada aikaan myös yhteiskunnallisen läpinäkyvyyden elementti. Tämä lasirakentamisen yhteiskunnallinen ulottuvuus tulee kuitenkin esille vasta siinä vaiheessa, jota Benjamin nimittää “toiseksi tekniikaksi”. Vaikka hän ei varsinaisesti puhu lasirakentamisen toisesta tekniikasta, tekee hän silti selkeän erottelun lasirakentamisen kahteen eri aikakauteen. Tätä voidaan siten ajatella ensimmäisen ja toisen tekniikan välisen suhteen kautta.
Ensimmäistä lasirakentamisen aikakautta ilmentää 1800-luvun loppupuoliskolla esimerkiksi maailmannäyttelyt, joista merkittävimpänä Benjamin kuvailee Joseph Paxtonin suunnittelemaa lasirakenteista Kristallipalatsia, joka toimi näyttelyhallina vuoden 1851 Lontoon maailmannäyttelyssä. Kuitenkin tässä lasi ilmensi 1920-luvun lasirakentamisen sijaan täysin päinvastaisia tendenssejä: lasinen palatsi nähtiin juuri materiaalinsa vuoksi hyvin erityisenä ja ainutkertaisena rakennuksena. Siksi lasin käyttö oli tässä mielessä 1800-luvulla Benjaminin mukaan vielä liian ennenaikaista (Benjamin, 2014a, s. 69).

Sen sijaan ensimmäinen maailmansota ja teknisen uusinnettavuuden kehitys 1900-luvun alussa muuttavat tilanteen monella tapaa. Lasin teollinen valmistaminen siirtyy siis "toisen tekniikan" vaiheeseen, jolloin esimerkiksi Bauhausin jäsenet tunnistavat siihen liittyvät mahdollisuudet ajatella yhteiskunnan luokkasuhteita uudella tavalla. Merkittävää onkin, että lasitaloa ei enää yhdistetä mihinkään maailmannäyttelyn kaltaiseen suureen tai poikkeukselliseen tapahtumaan, vaan Benjamin viittaa anonyymisti väkeen, joukkoihin sekä nomadimaiseen liikkuvaan elämäntapaan määritellessään lasitalon tyypilliset asukkaat:

Scheerbartille, palataksemme vielä häneen, on ensiarvoista, että hänen väellään - ja heidän esikuvansa mukaisesti myös hänen aikalaisillaan - on asianmukaiset asumisolot: he asuvat siirrettävissä, liikuteltavissa lasitaloissa, jollaisia Loos ja Le Corbusier samaan aikaan rakensivat.(Benjamin, 2014, s. 137.)

Vasta 1920-luvulla lasiarkkitehtuuri saavuttaa siis tason, jolle voidaan Benjaminin mukaan ajatella myös jonkinlainen massaulottuvuus ja tätä kautta laajempi emansipatorinen voima. Tästä eteenpäin lasi ei siis ainoastaan merkitse Benjaminille esteettistä transformaatiota auraattisesta arkkitehtuurista uudenlaisiin rakentamisen muotoihin massatuotannon kehittyessä. Pikemminkin lasin teollinen valmistaminen mahdollistaa myös sen, että arkkitehtuuri alkaa saada elokuvan tavoin uudenlaisia yhteiskunnallisen 
läpinäkyvyyden tehtäviä. Tältä osin kyse on elokuvan tavoin "toisen tekniikan" kehittymisestä ja sen siirtymisestä osaksi taiteen uusinnettavuudessa tapahtuneiden muutosten ja massojen välisen suhteen uutta ajattelua.

\section{Lopuksi}

Olemme tässä artikkelissa lukeneet Walter Benjaminin myös kulttuuripolitiikan alaan kuuluvassa tutkimuksessa klassikkotekstinä pidettyä Taideteos teknisen uusinnettavuuden aikakaudella -esseetä. Näkökulmamme on keskittynyt erityisesti tekstin (taide)poliittiseen merkitykseen. Olemme painottaneet, että Benjamin käsitteellistää uusien teknisten ja materiaalisten tuotanto- ja uusintamistapojen vaikuttavan välillisesti poliittisella tavalla, sillä ne tuottavat uusia sosiaalisia suhteita, mahdollistavat uusia kokemuksia ja muokkaavat tekijä-yleisö-suhdetta. Sen sijaan, että taiteen poliittista merkitystä etsittäisiin vain sen sisällöistä, Benjamin huomioi etenkin taiteen ja kulttuurin vastaanottoa muotoilevan tekniikan.

Olemme lukeneet Taideteos-esseetä ennen kaikkea näkökulmasta, joka painottaa taiteen tuotannon ensimmäisen ja "toisen tekniikan" käsitteellistä erottelua. Erityisesti Taideteos-esseen toisessa versiossa käsitelty "toinen tekniik- ka" viittaa sellaisiin toimenpiteisiin, joilla yleisön on mahdollista kollektiivisesti ottaa haltuun taiteentuotannon prosesseja. Elokuvaa ja arkkitehtuuria esimerkkeinään käyttäen Benjamin hahmottelee mahdollisuuksia massoille päästä tekemisiin sellaisten kulttuuriartefaktien kanssa, jotka aikaisemmin oli varattu vain harvoille.

Taiteen "toinen tekniikka" ei siis merkitse ainoastaan uudenlaista tapaa tuottaa taidetta, vaan sen toimintapiirin laajentamista (Benjamin, 2014b, s. 29). Tässä erilaisten avantgardeliikkeiden historiallinen rooli on keskeinen. Benjaminin tulkinta avantgardesta on eklektinen, mutta käsittelemämme elokuva ja arkkitehtuuri tuovat esiin, että Benjaminin keskeisimpiä viittauspisteitä yhdistää yhteiskunnallisen läpinäkyvyyden ajatus. Lasiarkkitehtuurin kohdalla läpinäkyvyys on ilmeistä, kun taas äänielokuvan "läpi" voimme ajatella kuuluvan ääniä, jotka ovat peräisin massojen urbaanista elämänpiiristä ja sen tuotannosta. Kyse ei ole realismista, vaan siitä, että elämästä tuttu osatekijä muotoillaan taiteessa uudelleen, vieraannutetaan tai abstrahoidaan, ja näytetään massoille uutta asennoitumista vaativana ongelmana. Nähdäksemme tässä hahmottuu kiinnostava ajatus uuden tekniikan ja sosiaalisen emansipaation välisestä suhteesta ja siitä millä tavalla uudenlaiset taiteen tuotannon tavat kykenevät laajemminkin pohjustamaan uusia poliittisia avauksia. ${ }^{9}$

\section{Kirjallisuus}

Benjamin, W. (1977). Reply [to Adorno]. Teoksessa F. Jameson (toim.) Aesthetics and Politics (134-141). London: Verso.

Benjamin, W. (1989). Messiaanisen sirpaleita: Kirjoituksia kielestä, historiasta ja pelastuksesta. Kääntänyt M. Koski, K. Rahkonen, E. Sironen \& R. Sironen. Helsinki: Tutkijaliitto.

Benjamin, W. (1991a). Gesammelte Schriften I. Frankfurt am Main: Suhrkamp.

Benjamin, W. (1991b). Gesammelte Schriften VII.
Frankfurt am Main: Suhrkamp.

Benjamin, W. (2004). On the Present Situation of Russian Film. Teoksessa Y. Tsivian (toim.) Lines of Resistance. Dziga Vertor and the Twenties (210-214). Sacile, Pordenone: Le Giornate del Cinema.

Benjamin, W. (2012). Werke und Nachlass. Kritische Gesamtausgabe. Frankfurt am Main: Suhrkamp.

Benjamin, W. (2014a). Keskuspuisto: Kirjoituksia 
kapitalismista, suurkaupungeista ja taiteesta. Kääntäneet T. Viitahuhta \& E. Viren. Helsinki: Tutkijaliitto.

Benjamin, W. (2014b). Taideteos teknisen uusinnettavuutensa aikakaudella. Suomentanut Miika Luoto. IssueX, 3, 28-29.

Benson, T. O. (toim.) (2002). Central European Avant-gardes: Exchange and Transformation, 1910-1930. Cambridge (MA): MIT Press.

Droste, M. (2002). Bauhaus 19 19-1933. Kääntänyt R. Bargsen. Köln: Taschen.

Elo, M. (2008). Walter Benjaminin mediaestetiikan erannoista: luovien politiikkaan. Teoksessa O.-J. Jokisaari, J. Parikka \& P. Väliaho (toim.) In medias res. Hakuja mediafilosofiaan (208-239). Turku: Eetos.

Forgacs, E. (1995). The Bauhaus Idea and Bauhaus Politics. Budapest: Central European University Press.

Gough, M. (2002). Paris, Capital of the Soviet Avant-garde. October, 101, 53-83.

Gumbrecht, H., U. \& Marrinan, M. (toim.) (2003). Mapping Benjamin: The Work of Art in the Digital Age. Stanford: Stanford University Press.

Hansen, M. (1987). The Blue Flower in the Land of Technology. New German Critique, 40, 179-224.

Hicks, J. (2007). Dziga Vertov: Defining Documentary Film. London: I. B. Tauris.

Hobsbawm, E. (1973). Revolutionaries. Contemporary Essays. London: Phoenix.

Kahn, D. (2001). Noise, Water, Meat: A History of Sound in the Arts. Cambridge (MA): MIT Press.

Le Corbusier (2004). Kohti uutta arkkitehtuuria. Kääntänyt P. Nurminen. Helsinki: Avain.

Leslie, E. (1997). On making-up and breaking-up: woman and ware, craving and corpse in Walter Benjamin's Arcades Project. Historical Materialism, 1 (1), 66-90.

Leslie, E. (2000). Walter Benjamin: Overpowering Conformism. London: Pluto Press.

Leslie, E. (2002). Hollywood Flatlands. Animation, critical theory and the avant-garde. London: Verso.

Lindroos, K. (1998). Now Time / Image Space. Temporality of Politics in Walter Benjamin's Philosophy of History and Art. Jyväskylä: SoPhi.

Mertins, D. (1996). The Enticing and Threatening Face of Prehistory: Walter Benjamin and the Utopia of Glass. Assemblage, 29 (1), 7-23.

Michelson, A. (1984). Introduction. Teoksessa A. Michelson (toim.) Kino-eye The Writings of Dziga Vertov (xv-lxi). Berkeley: University of California Press.

Moisio, O.-P. (2004). Unia Alvar Aallon seinällä.
Teoksessa R. Koikkalainen (toim.) Koettu kampus (7-26). Jyväskylä: Jyväskylän yliopiston julkaisusarja.

Mumford, E. (2002). The CIAM Discourse on Urbanism, 1928-1960. Cambridge (MA): MIT Press.

Nikkilä, A. (2010). Mekaanisen sian kuviteltu nylkeminen. Idäntutkimus, (1/2010), 42-51.

Petriç, V (1984). Constructivism in Film. The Man with the Movie Camera - A Cinematic Analysis. London: Cambridge University Press.

Roberts, J. (2015). Revolutionary Time and the Avant-garde. London: Verso.

Rowe, C., \& Slutzky, R. (1971). Transparency: Literal and phenomenal. Perspecta, 8, 45-54.

Schwartz, F. J. (2001). The Eye of the Expert: Walter Benjamin and the Avant-garde. Art History, 24 (3), 401-444.

Vertov, D. (1984a). First Steps. Teoksessa A. Michelson (toim.) Kino-eye. The Writings of Dziga Vertov (1 12-1 15). Berkeley: University of California Press.

Vertov, D. (1984b). Sound March. Teoksessa A. Michelson (toim.) Kino-eye. The Writings of Dziga Vertov (289-293). Berkeley: University of California Press.

Ward, J. (2001). Weimar Surfaces: Urban Visual Culture in 1920s Germany. Berkeley: University of California Press.

Wolin, R. (1994). Walter Benjamin. An Aesthetic of Redemption. Berkeley: University of California Press.

\section{Loppuviitteet}

1. Avantgarde voidaan ymmärtää monella tapaa. Seuraamme tässä erityisesti taideteoreetikko John Robertsin määritelmää avantgardesta. Robertsille (2015) avantgarde on työn, tuotannon ja poliittisten mallien samanaikaista kritiikkiä ja vaihtoehtoisten mallien muotoilua “taiteen laajennetulla kentällä”. Avantgarde edustaa Robertsin mukaan mahdollisuutta kyseenalaistaa perinteisten tekniikoiden ja representaatioiden avulla myös laajempia yhteiskunnallisia, työhön ja tuotantoon liittyviä rakenteita sekä osallistua kriittisesti niiden uusintamisesta käytyyn kiistaan.

2. On merkittävää, että Benjamin kirjoittaa lainausmerkeissä “aitoudesta”, mutta tekstin 
suomennoksessa lainausmerkit muuttuvat kursivoinniksi, muuttaen etäännyttävän korostuksen alleviivaavaksi (vrt. Benjamin, 1989, s. 146; Benjamin, 1991, s. 356).

3. Viittaamme tämän suomentamattoman version kohdalla GS-laitoksen niteeseen VII.1, s.350-384. Poikkeuksen muodostaa kyseisen version luku VI, joka on ilmestynyt Miika Luodon suomentamana vuonna 2014 ja johon viittaamme suoraan.

4. Tämä kaksinaisuus muistuttaa historioitsija Eric Hobsbawmin 1970-luvulla antamaa kaksiosaista vastausta kysymykseen siitä, mikä tekee ihmisestä vallankumouksellisen. Näitä ovat yhtäältä melko vaatimattomien, omaa ja läheisten elämää koskevien toiveiden täydellinen näköalattomuus nykyisten olojen vallitessa sekä toisaalta päinvastainen ajatus siitä, että vallankumous on kuitenkin mahdollinen (Hobsbawm, 1973, s. 248).

5. "In der Repräsentation des Menschen durch die Apparatur hat dessen Selbstentfremdung eine höchst produktive Verwertung erfahren." Suomennos tekijöiden.

6. Entusiasmin vaikutuksesta etenkin venäläiseen noise-musiikille, ks. Nikkilä, 2010.

7. Äänielokuvan tavoin Benjamin on toki tietoinen myös siitä, että lasirakentaminen voi kääntyä myös itseään vastaan ("sopii vain toivoa, ettei lasikulttuuri kohtaa liian monia vastustajia”) (Benjamin, 2014a, 138). Myös Benjaminin läheinen kollega Ernst Bloch on kirjoittanut toisen maailmansodan jälkeisestä perspektiivistä, että erityisesti lasiarkkitehtuuri, joka toki oli emansipatorisen politiikan kannalta innostava hanke, epäonnistui laajemmassa yhteiskunnallisen läpinäkyvyyden uudistamisessa (Moisio, 2004, s. 17)

8. Talon omisti Benjaminin tuttavapiiriin kuulunut Ranskan kommunistisessa puolueessa näkyvästi vaikuttanut lääkäri Jean Dalsace. Maria Gough esittää, että Benjaminin lukuisat vierailut kyseisessä rakennuksessa toimivat hyvin tärkeänä vaikuttajana Benjaminin kirjoituksille lasiarkkitehtuurin emansipatorisesta voimasta (Gough, 2002, s. 57).

9. Kiitämme Kulttuuripolitiikan tutkimuksen vuosikirjan toimituskuntaa sekä kahta vertaisarvioijaa huomioista ja korjausehdotuksista tekstiin. 